\title{
WILL SUBTERRANEAN TERMITES CONSUME LANDSCAPE MULCHES?
}

\section{by Mary L. Duryea, ${ }^{1}$ Jacob B. Huffman, ${ }^{2}$ R. Jeffery English, ${ }^{3}$ and Weste Osbrink ${ }^{4}$}

\begin{abstract}
Subterranean termites live in colonies in the soil in both temperate and tropical regions throughout the world. These termites feed on cellulose and are a major cause of damage to wood in use. Organic tree-based mulches provide many benefits to a landscape, yet recently, questions about whether they could harbor or be a source of food for termite colonies have arisen. In a series of 2 no-choice food experiments, this study investigated whether termites would consume 6 landscape mulches: cypress, eucalyptus, melaleuca, pine bark, pine straw, and a utility pruning mulch, and 5 woods: pine sapwood, cypress heartwood and sapwood, and melaleuca heartwood and sapwood. In the wood experiments, termites consumed pine and cypress sapwood but did not consume the cypress heartwood or melaleuca sapwood or heartwood. In the pine and cypress sapwood, $64 \%$ to $77 \%$ of the termites survived, while melaleuca and cypress heartwood had fewer than 15\% live termites. In Experiment 1 , termites ate more of the utility mulch than any other mulch. In Experiment 2, termites consumed all mulches except melaleuca, which was the least desirable food in both experiments. Correlations with chemical characteristics were significant for both nitrogen and phosphorus $(r=0.91$ and 0.96 ), showing that termites preferred mulches with higher $\mathrm{N}$ and $\mathrm{P}$ concentrations. In both experiments termite consumption was also correlated with l-year decomposition of mulches in another study. Because termites ate most mulches, further investigation is necessary to determine whether landscape mulches around building foundations could harbor or support termite colonies.
\end{abstract}

Key Words. Landscape mulches; mulches; subterranean termites; termites.

Subterranean termites occur throughout the temperate and tropical regions of the world and cause the majority of damage to wood in use (Anonymous 1997; Moore 1979). They live in the soil in colonies that can number up to 1 million workers and soldiers and, in nature, their role as decomposers of dead and fallen trees is a valuable one (Moore 1979). However, termites also consume wood in service, and so there is great interest and concern over their threat to wooden buildings and structures.
The dark southern subterranean termite, Reticulitermes virginicus (Banks), and eastern subterranean termite, Reticulitermes flavipes (Kollar), are 2 of the 5 principal subterranean termite species in the United States, causing $95 \%$ of the termite damage to wooden structures (Forschler and Lewis 1997). They do not build distinct nests but instead have dispersed colonies underground with a collection of feeding sites (Ballard 1997). Subterranean termites forage for food as far as $75 \mathrm{~m}$ (250 ft) from their colony. To mitigate the effect of air currents and reduce attack from ants, these termites build mud tubes between the soil and food sources.

Landscape mulches are commonly used in today's urban forest to provide many benefits, including water and soil conservation, weed control, soil temperature buffering, and soil organic matter improvement (Watson 1988; Stinson et al. 1990; Gleason and Iles 1998). These benefits and the increasing interest in using yard waste have resulted in a wide array of mulches being used for weed management and decorative purposes around houses. Recently, questions have been raised about organic mulches being possible attractants to termites. The objectives of this study were to determine if 1 ) termites would actively consume various landscape mulches, 2) termites are able to survive on various landscape mulches, and 3 ) termites would survive after consuming heartwood and sapwood of 2 woods commonly used for landscape mulches.

\section{METHODS}

Colonies of $R$. virginicus and $R$. flavipes were collected from logs at the Austin Cary Memorial Forest and the yard of a residence in Gainesville, Florida, in winter 1997 and spring 1998. Termite species were identified according to characteristics described by Scheffrahn and Su (1996a; 1996b). Then, 2 no-choice food experiments were conducted. In Experiment 1, survival of both $R$. virginicus and $R$. flavipes on 6 different landscape mulches and 5 separate pieces of heartwood and 
sapwood was measured. Experiment 2 compared the same mulches and woods with only $R$. flavipes.

The 6 mulches, each containing unknown proportions of bark, sapwood, heartwood, twigs, and leaves were:

- cypress (Taxodium distichum [L.] Rich. and Taxodium distichum var. nutans [Ait.] Sweet)

- eucalyptus (wood from Eucalyptus grandis W. Hill ex Maiden)

- melaleuca (Melaleuca quinquenervia [Cav.] S.T. Blake)

- pine bark (Pinus elliottii [Engelm.] and P. taeda [L.])

- pine straw (needles from P. elliottii [Engelm.])

- Gainesville Regional Utility (GRU) mulch containing utility prunings from oaks (Quercus laurifolia Michx., Q. rubra [L.], and Q. virginiana Mill.) and cherry (Prunus serotina Ehrh.), with a small amount of cedar (Juniperus silicicola [Small] Bailey), camphor (Cinnamomum camphora [L.] J. Presl), and southern pines (Pinus spp.) chopped with a Woodchuck ${ }^{\circledR}$ Disk Chopper.

The other 5 wood mulches were purchased from commercial gardening stores.

The mulches were air dried for 3 days and dried in a desiccator for 3 more days. One gram of each mulch $(0.7 \mathrm{~g}$ in Experiment 2) was placed in a piece of vinyl Tygon ${ }^{\circledR}$ tubing $0.8 \mathrm{~cm}(0.3 \mathrm{in}$.) diameter by $8.5 \mathrm{~cm}$ (3.4 in.) long, and $2 \mathrm{~mL}$ of water was added. Each tube was laid in a plastic $85 \times 15 \mathrm{~mm}(3.3 \times 0.6 \mathrm{in}$.) petri dish that had been sanded with very fine sandpaper (to create a nonslip surface for the termites). Fifty-five workers, 3rd-instar or older as determined by size, were placed in each petri dish along with 1 to 2 soldiers. The petri dishes were closed but not sealed to allow air to enter. The 7 blocks of petri dishes were placed in a humidity chamber where the humidity was kept at a constant $98 \%$ and air temperature was maintained at $24^{\circ} \mathrm{C}\left(75^{\circ} \mathrm{F}\right)$. To determine if termites needed to eat during the experimental period, 1 more treatment was added to Experiment 2; each block had 1 petri dish with no food (mulch or wood) and 55 termites.

Wood samples from 3 tree species were also tested. The 5 samples were:
- pine sapwood (Pinus elliottii [Engelm.]) as a standard

- cypress sapwood

- cypress heartwood (Taxodium distichum var. nutans [Ait.] Sweet)

- melaleuca sapwood

- melaleuca heartwood (Melaleuca quinquenervia [Cav.] S.T. Blake)

The wood samples were sawn from air-dried woods; each piece was approximately $2 \mathrm{~mm}$ thick $\times 8$ $\mathrm{mm}$ wide $\times 52 \mathrm{~mm}$ long $(0.08 \times 0.3 \times 2$ in. $)$ and weighed from 0.53 to $0.71 \mathrm{~g}$. Pine sapwood was used as a standard because it is known to be a desirable food for termites. The woods were air dried and desiccated as with the mulches. Then they were placed in Tygon tubes, $2 \mathrm{~mL}$ of water were added, and 55 termites were added to each dish. The petri dishes were placed in the same humidity chamber as the mulches.

Each week for 3 weeks, we observed the termites and noted the number of active, inactive, and dead individuals. At the end of the experiments (3 weeks) we counted the number of live termites, removed the mulches and woods from the tubes, and allowed them to dry in air for 3 days and then for 3 days in the desiccator. The dried samples were then weighed to compare pre- and post-feeding weights for each type of mulch and wood.

The experiments were randomized complete block designs with 7 blocks. The mulches contained 6 mulches $\times 7$ blocks $=42$ petri dishes. The woods contained 5 woods $\times 7$ blocks $=35$ petri dishes. In addition, in Experiment 2 each block had a dish with termites but no food.

\section{Statistical Analyses}

All data were subjected to an analysis of variance using SAS (Statistical Analysis System, SAS Institute, Cary, NC). All percentages were analyzed as untransformed values. Plots of residuals versus fitted values demonstrated a random scatter of the data points, showing that transformation of the data was not necessary. After determining the significance level for each analysis, we employed a Tukey's Studentized Range Test for each variable. Correlation analyses between mulch consumption and termite survival and mulch characteristics determined from another study (chemical 


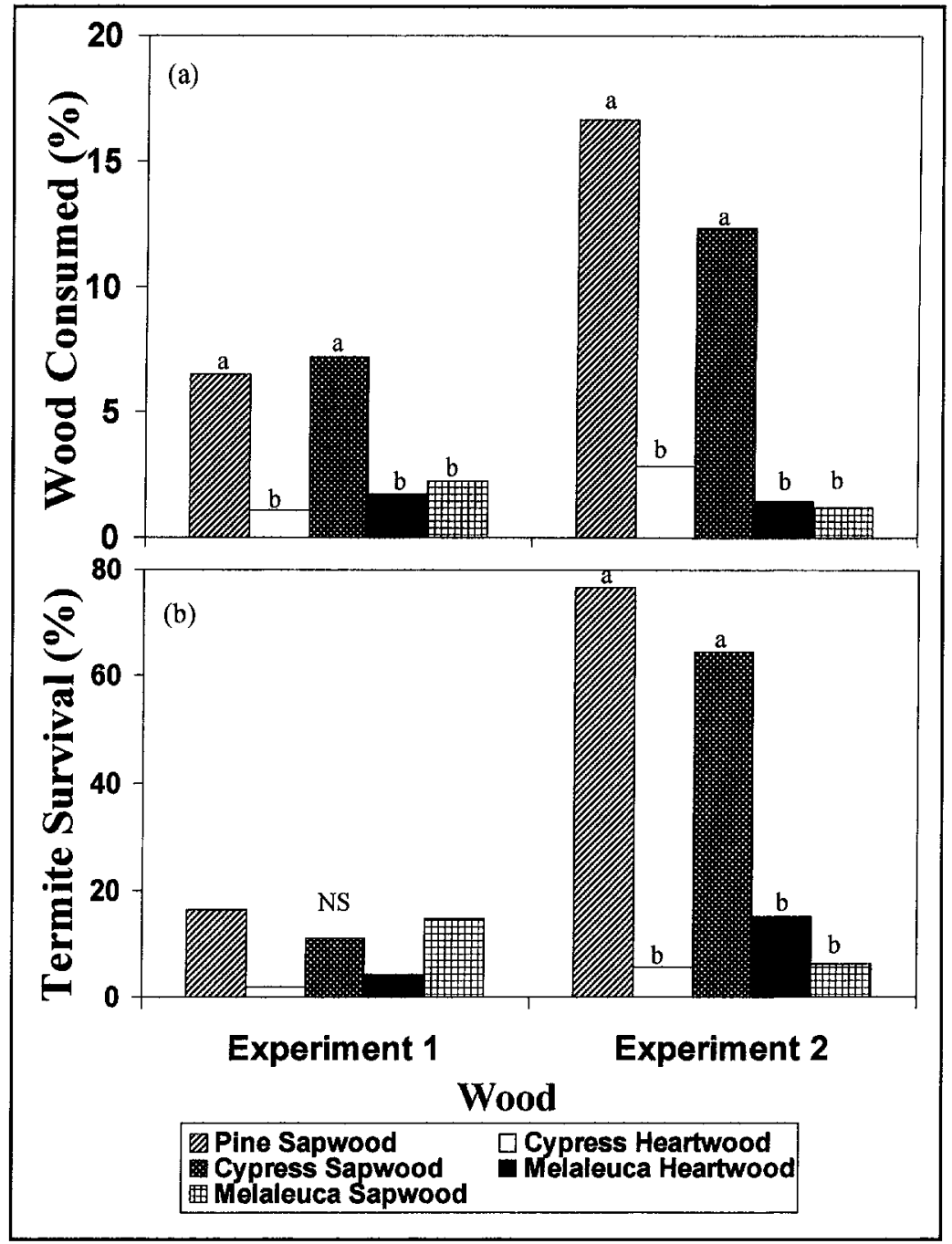

Figure 1.Termite consumption of 5 woods (a) and termite survival (b) during two 3-week no-choice food experiments. (Treatments with no letter in common are significantly different at $P \leq 0.05$; NS means not significantly different at $P \leq 0.05$.)

characteristics such as nutrients, carbohydrates, hydroxylated aromatic compounds and lignin, and decomposition rate of mulches) (Duryea et al. 1999) were conducted.

\section{RESULTS \\ Moisture Content}

Although wood in structures where termites are feeding usually contains from $8 \%$ to $12 \%$ moisture, the termites obtain necessary moisture by periodic visits to the soil. If water is not available, wood must con- tain at least 30\% moisture to sustain termites (Anonymous 1997). Thus, it was extremely important in the experiments that adequate moisture contents were achieved in woods and mulches in the 98\% humidity chamber. The moisture content of mulches and woods during the experiments averaged $60 \%$ and $30 \%$, respectively.

Because of possible volatilization of chemicals, we did not oven dry the woods and mulches before the experiments. Instead desiccators were used before and after the experiments to standardize the weights. Moisture contents of desiccated mulches and woods averaged $6 \%$ and $2 \%$, respectively, before the experiments and $6 \%$ and $5 \%$ after the experiments, showing that the desiccation was consistent and that experimental weight loss was due to termite consumption.

\section{Experiment 1}

In separate analyses for Experiment 1 , results were the same for $R$, virginicus and $R$. flavipes and were therefore pooled. Termite consumption of the pine sapwood standard and cypress sapwood was significantly greater than their consumption of cypress heartwood and melaleuca woods (Figure la). A large percentage of the less vigorous species, $R$. virginicus, was used in Experiment 1 , and by the end of the experiment less than $20 \%$ of the termites were alive with no survival differences for termites feeding on the different woods (Figure 1b).

Termites ate GRU mulch more than any other mulch and more than the pine sapwood (Figure 2a). Survival in the various mulches was not different (Figure $2 b$ ).

Both nitrogen $(\mathrm{N})$ and phosphorus $(\mathrm{P})$ concentrations in the mulches (Duryea et al. 1999) were correlated ( $r=0.91$ and 0.96 , respectively) with mulch 


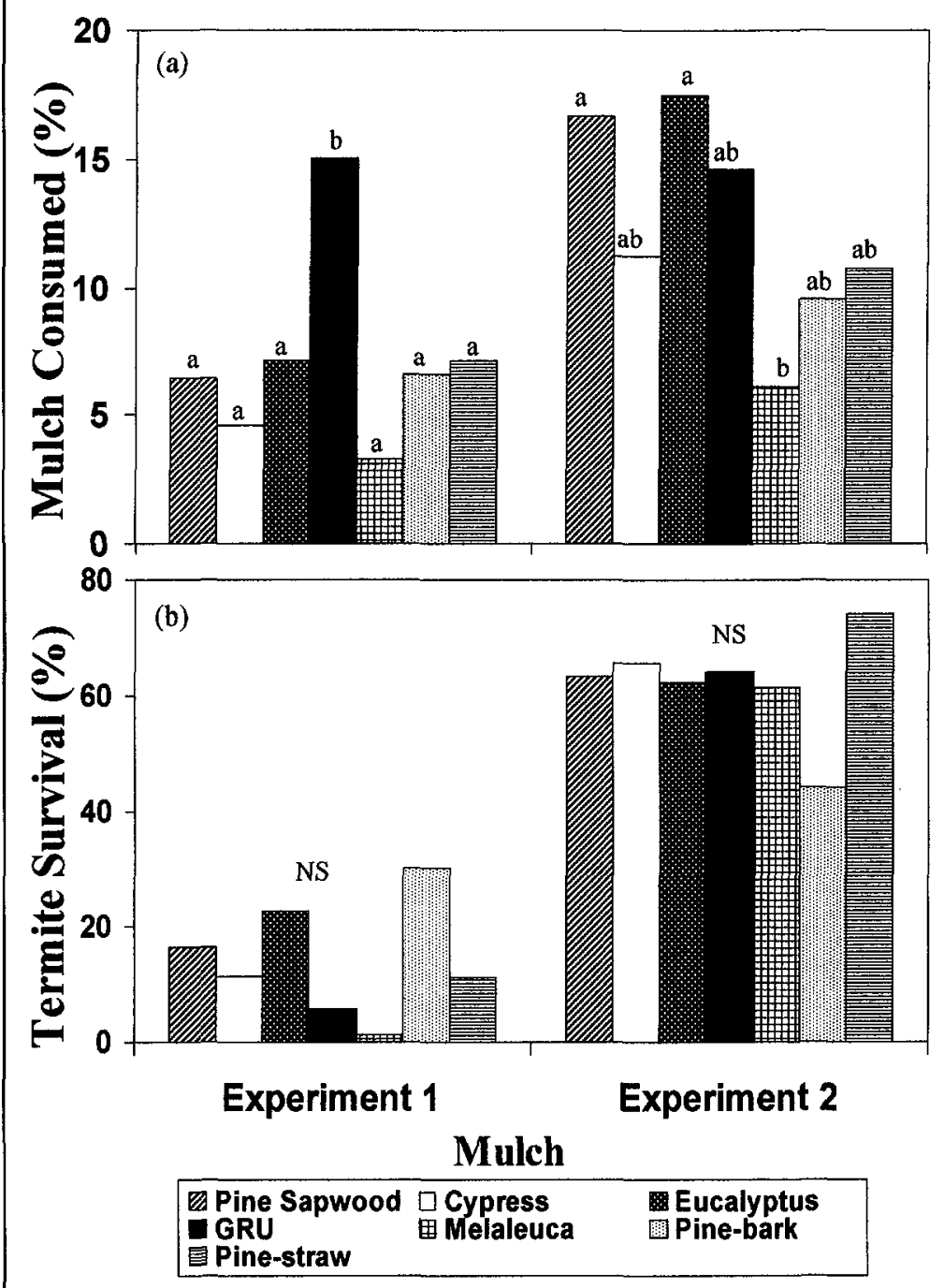

Figure 2.Termite consumption of 6 landscape mulches (a) and termite survival (b) during two 3-week no-choice food experiments. (Treatments with no letter in common are significantly different at $\mathbf{P}$ $\leq 0.05$; NS means not significantly different at $P \leq 0.05$.) positively correlated $(r=0.84, P=$ 0.04 ) with mulch consumption; the mulches that decomposed quickly in the field were also the ones most consumed by termites.

\section{Experiment 2}

At the end of Experiment 2, only $8 \%$ of the termites in the treatment without food were alive, indicating that few could live for 3 weeks under these conditions without food. In contrast, $77 \%$ of the original population of termites survived on pine sapwood.

Again as in Experiment 1, termites consumed the pine sapwood standard and cypress sapwood, while less than $3 \%$ of the cypress heartwood and melaleuca heartwood and sapwood was consumed (Figure la). By the end of Experiment 2, with $R$. flavipes, the pine and cypress sapwoods had $64 \%$ and $77 \%$ surviving termites, respectively, while melaleuca and cypress heartwood had less than $15 \%$ survival (Figure 1b).

In Experiment 2, termites consumed all the mulches. However, consumption of eucalyptus mulch was greater than melaleuca (Figure 2a). A statistical analysis of pooled results from both experiments showed that melaleuca was the least preferred mulch $(P=0.001)$. Termite survival at the end of both experiments was the same for all mulches (Figure 2b). Mulch consumption was weakly correlated with mulch decomposition $(r=0.74, P=0.09)$ with no other significant correlations. consumption in Experiment $1(P=0.01$ and 0.003$)$ showing that as $\mathrm{N}$ and $\mathrm{P}$ concentrations increased, the termites ate more mulch. Decomposition rates of mulches in the landscape (Duryea et al. 1999) were also

\section{DISCUSSION Woods}

In both experiments, termites consumed the pine sapwood standard and the cypress sapwood, while not 
consuming either cypress heartwood or melaleuca. In addition, in Experiment 2, survival of $R$. flavipes was highest for pine and cypress sapwood and lowest for melaleuca and cypress heartwood. In other studies, survival of $R$. flavipes during forced feeding on cypress was $22 \%$ compared to $81 \%$ for slash pine (Smythe and Carter 1969) and $1 \%$ and $72 \%$ for melaleuca and slash pine (Carter and Huffman 1982).

Heartwoods are known to be repellent or sometimes toxic to termites (Johnston et al. 1972; Moore 1979). Termite-resistant woods listed by Johnston et al. (1972) are heartwoods of California redwood (Sequoia sempervirens [D. Don] Endl.), southern tidewater red cypress (Taxodium distichum var. nutans [Ait.] Sweet), very pitchy southern pine, called lighterwood, (Pinus [L.]), and heartwood of red cedar (Juniperus virginiana [L.]). In his index of termite-resistant woods, Wolcott (1950) rated cypress heartwood as very resistant and cypress sapwood as very susceptible. In a study of $R$. flavipes' feeding response, redwood and cypress were the least-favored species and slash and loblolly pine the most (Smythe and Carter 1969). Extracts from cypress heartwood showed that extracted allelochemicals operated as feeding deterrents, and the accompanying mortality from cypress heartwood was due to starvation (Scheffrahn et al. 1988).

\section{Mulches}

In Experiment 1, termites ate GRU mulch more than any other mulch and more than pine sapwood. Another study that compared 90 U.S. hardwoods showed that red oak and black cherry sapwood, 2 of the woods in the GRU mulch, were susceptible and moderately susceptible to termites (Carter and Dell 1981). In a study of feeding response of $R$. flavipes to 11 woods, black cherry sapwood was placed at the top of the favorable list along with loblolly and slash pines, while cypress and redwood were unfavorable foods (Smythe and Carter 1969).

In addition to melaleuca woods being undesirable food for termites, a statistical analysis of pooled results from both experiments showed that melaleuca was the least-preferred mulch. A study of termite feeding on melaleuca heartwood resulted in $1 \%$ survival and $2 \%$ wood weight loss compared to slash pine sapwood with $72 \%$ survival and $28 \%$ weight loss (Carter and Huffman 1982). The study of 90 hardwoods showed some hardwoods to be antitermitic (Carter and Dell 1981). A study in Canada investigated extracts from 2 street-tree species with differential termite infestation. Extracts from the less-susceptible tree species (Ailanthus altissima [Mill.] Swingle) elicited negative responses from termites as compared to the susceptible species (Aesculus hippocastanum L.) (Grace 1991). Reticulitermes flavipes survived better on black walnut than redwood and cypress extracts applied to sawdust (Carter and Smythe 1972).

Our results indicate that termites were consuming all the mulches except melaleuca. The resistance of certain woods to termites could be due to their chemical makeup, which could make them distasteful, repellent, or toxic (Carter and Dell 1981). The termites without food starved and died, while those feeding on the other mulches and pine sapwood averaged $62 \%$ survival. Today's cypress mulch is harvested from young trees with little or no heartwood, and in Experiment 2, termites consumed the same amount (11\% and 12\%) of cypress mulch and cypress sapwood, respectively, over the 3-week experimental period. Waller and La Fage (1988) noted that termites consume dead wood and fresh or decaying litter, meaning twigs, branches, dead grass, and leaves. When listing the principal food of termites, Johnston et al. (1972) noted that termites feed on cellulose from wood and other plant tissues, including portions of buildings, fence posts, utility poles, and any other wood product. It is not surprising that termites also feed on landscape mulch, especially in no-choice experiments.

Other authors have noted susceptibility and resistance of different woods. When discussing wood preservation, Tamblyn (1984) noted that untreated eucalyptus sapwood is susceptible to decay and termite attack. Cypress heartwood, also knowm as tidewater red cypress, though scarce today, has long been known for its termite and decay resistance (Johnston et al. 1972; Moore 1979).

\section{What Makes Mulch Desirable}

In Experiment 1 , as $\mathrm{N}$ and $\mathrm{P}$ concentrations in mulches increased, the termites ate more mulch. Although dietary $N$ needs are still somewhat unknown, there is some evidence that termites select foods with higher $\mathrm{N}$ contents (Prestwich et al. 1980). Bacteria in the termite's gut fix atmospheric N (Curtis and Waller 1995), and termite tissues incorporate $\mathrm{N}$, but the im- 
portance of $\mathrm{N}$ to termites is still unclear (Waller and La Fage 1988).

In both experiments, decomposition rates were correlated with termite consumption. Termites are decomposers in the forest, and it appears that they like the same materials as the other decomposer organisms. Decay fungi are known to play an important role in termite activity by partially decaying wood and making it more digestible to termites (Kofoid 1946). Fungi also contain $\mathrm{N}$, an important element in the termite's diet (Moore 1979). In our study, hyphal growth of fungi was noticeably abundant in GRU mulch, one of the most favored mulches to termites. Waller and La Fage (1988) noted many advantages of termites consuming partially decayed materials: enhanced $\mathrm{N}$ and nutrient content, increased moisture content, and many others.

\section{CONCLUSIONS}

Subterranean termites consumed mulches in this study. If mulches do attract and support termite colonies in the landscape, the next question is whether this is a concern. Do mulches provide needed food while termites are foraging for other wood materials around or in a house? Do chemical barriers (pesticides) and other preventatives such as building design provide enough protection for houses so that termite colonies in mulch are unimportant? Little is known or mentioned in the literature about mulches and termites. Warnings about not leaving pieces of wood or stakes as termite attractants after house construction are common though. One publication noted that when construction is complete on a new house, every "piece of wood that can be picked up between the tines of a common garden rake should be removed" (Moore 1979). Another publication notes that moist, warm soil containing an abundant supply of cellulose material is a termite's optimal environment (Johnston et al. 1972). They define "cellulose material" as scraps of lumber, stakes, stumps, and roots left in the soil. One of the prerequisites for subterranean termites and wood-decaying fungi is for the wood to be in reasonably close proximity to the soil surface (Moore 1979), as mulch is. Because water is necessary for termite survival, irrigation systems might result in favorable conditions for termites. Further research on mulches and termites is warranted to determine if we should be concerned about using mulches around houses. Research is also needed on possible repellent mulches, such as melaleuca, which might serve as an additional barrier for household protection against termites.

\section{LITERATURE CITED}

Anonymous. 1997. Termite basics: A pre-swarm review. Pest Control Technol. 25(2):64-67.

Ballard, J. 1997. Termite baiting 101. Pest Control 65(2):3040.

Carter, F.L., and T.R. Dell. 1981. Screening selected American hardwoods for natural resistance to a native subterranean termite, Reticulitermes flavipes (Kollar). USDA Forest Serv. South. For. Exp. Sta. Res. SO-176. New Orleans, LA. $10 \mathrm{pp}$.

Carter, FL., and J.B. Huffman. 1982. Termite responses to wood and extracts of melaleuca. Wood Sci. 14(3):127133.

Carter, FL., and R.V. Smythe. 1972. Extractives of baldcypress, black walnut and redwood and survival of the Eastern subterranean termite, Reticulitermes flavipes. Ann. Entomol. Soc. Am. 65(3):687-689.

Curtis, A.D., and D.A. Waller. 1995. Changes in nitrogen fixation rates in termites (Isoptera: Rhinotermitidae) maintained in the laboratory. Ann. Entomol. Soc. Am. 88(6):764-767.

Duryea, M.L., R.J. English, and L.A. Hermansen. 1999. A comparison of landscape mulches: Chemical, allelopathic, and decomposition properties. J. Arboric. 25:8897.

Forschler, B., and V. Lewis. 1997. Why termites can dodge your treatment. Pest Control 65(2):42-53.

Gleason, M.L., and J.K. Iles. 1998. Mulch matters. Am. Nurseryman. February:24-31.

Grace, J.K. 1991. Behavioral ecology of subterranean termites and implications for control, pp 43-45. In Haverty, M.I., and W.W. Wilcox (Eds.). Proc. Symp. Current Research on Wood-Destroying Organisms and Future Prospects for Protecting Wood in Use. 13 September 1989. USDA For. Serv. Gen. Tech. Rep. PSW-128. Berkeley, CA.

Johnston, H.R., V.K. Smith, R.H. Beal. 1972. Subterranean termites, their prevention and control in buildings. USDA For. Serv. Home Garden Bull. No. 64. Washington, DC. $30 \mathrm{pp}$.

Kofoid, C.A. 1946. Biological backgrounds of the termite problem, pp 1-12 In Kofoid, C.A., (Ed.). Termites and termite control. University of California Press, Berkeley, CA.

Moore, H.B. 1979. Wood-inhabiting insects in houses: Their identification, biology, prevention and control. 
USDA For. Serv. and Dept. of Housing and Urban Devel. 133 pp.

Prestwich, G.D., B.L. Bentley, and E.J. Carpenter. 1980. Nitrogen sources for neotropical nasute termites: Fixation and selective foraging. Oecologia 46:397401.

Scheffrahn, R.H., R. Hsu, N. Su, J.B. Huffman, S.L. Midland, and J.J. Sims. 1988. Allelochemical resistance of bald cypress, Taxodium distichum, heartwood to the subterranean termite, Coptotermes formosanus. J. Chem. Ecol. 14(3):765-775.

Scheffrahn, R.H., and N. Su. 1996a. Key to termite soldiers of Florida. University of Florida IFAS Res, and Education Center Research Report FTL 96-2.

Scheffrahn, R.H., and N. Su. 1996b. Key to winged termites of Florida. University of Florida IFAS Res. and Education Center Research Report FTL 96-3.

Smythe, R., and F.L. Carter. 1969. Feeding responses to sound wood by the Eastern subterranean termite, Reticulitermes flavipes. Ann. Entom. Soc. Am. 62(2):335-337.

Stinson, J.M., G.H. Brinen, D.B. McConnell, and R.J. Black. 1990. Evaluation of landscape mulches. Proc. Fla. State Hortic Soc. 103:372-377.

Tamblyn, N.E. 1984. Preservation and preserved wood, pp 343-352. In Hillis, W.E., and A.G. Brown (Eds.). Eucalyptus for Wood Production. Academic Press. Orlando, FL.

Waller, D.A., and J.P. La Fage. 1988. Nutritional ecology of termites, pp 487-532. In Slansky, Jr., F., and J.G. Rodriguez (Eds.). Nutritional Ecology of Insects, Mites, Spiders, and Related Invertebrates. Wiley, New York, NY.

Watson, G.W. 1988. Organic mulch and grass competition influence tree root development. J. Arboric. 14(8):200-203.

Wolcott, G.N. 1950. An index to the termite-resistance of woods. Univ. Puerto Rico Agric. Exp. Sta. Bull. No. 85. Rio Piedras, PR. 26 pp.

Acknowledgements. We are grateful for the financial support for this study from the Florida Department of Agriculture and Consumer Services' 1997 Urban and Community Forestry Grant Program and the Florida Agricultural Experiment Station. We are thankful to Joe Wolf at Gainesville Regional Utility for repeatedly providing us with fresh utility mulch; and to Griffis Lumber and Sawmill Company, Overstreet Logging, Inc., and Southern Fuelwood for supplying the cypress and pine wood. In addition, we would like to thank Eliana Binelli and David Noletti for providing valuable field and laboratory analysis and assistance. This is Florida Agricultural Experiment Station Journal \#R-06738 of the Institute of Food and Agricultural Sciences, University of Florida, Gainesville, FL 32611.
${ }^{1 *}$ Professor, ${ }^{2}$ Professor Emeritus, and ${ }^{3}$ Biologist

School of Forest Resources and Conservation

University of Florida

PO. Box 110410

Gainesville, FL 32611-0410

${ }^{4}$ Research Entomologist

USDA Southern Regional Research Center

1100 Robert E. Lee Blvd.

New Orleans, LA 70124

"Corresponding author

Résumé. Les termites souterraines vivent en colonie dans le sol tout autant dans les régions tropicales que tempérées du monde. Ces termites se nourrissent de cellulose et sont une cause majeure de dommages au bois que l'on utilise. Le paillis organique autour de la base des troncs d'arbres procure de nombreux bénéfices aux aménagements paysagers bien que des questions récentes se sont pointées quant à la possibilité que le paillis puisse être un abris ou une source de nourriture pour les colonies de termites. Dans une série de deux expériences de choix unique de nourriture, nous avons étudié si les termites allaient consommer les paillis de six types différents (cyprès, eucalyptus, Melaleuca, écorce de pin, chaume de pin, copeaux d'élagage) ainsi que cinq types de bois (aubier de pin, aubier et bois de cour de cyprès, aubier et bois de cœur de Melaleuca). Dans les expériences avec le bois, les termites ont consommé l'aubier de cyprès et de pin mais pas le bois de coeur de cyprès ou encore l'aubier et le bois de cour de Melaleuca. Dans l'expérience no 1, les termites ont mangé plus de copeaux d'élagage que tout autre type de paillis et plus que d'aubier de pin (test contrôle). Le Melaleuca était la nourriture la moins désirable dans les deux expériences. Dans l'expérience no 2, les termites ont consommé tous les paillis sauf celui de Melaleuca. Les corrélations avec les caractéristiques chimiques étaient significatives pour à la fois l'azote et le phosphore $(\mathrm{r}=0,91$ et 0,96$)$, montrant ainsi que l'augmentation des concentrations de $\mathrm{N}$ et de $\mathrm{P}$ incitait les termites à consommer plus de paillis. Dans les deux expériences, la consommation des termites était aussi corrélée avec le taux de décomposition du paillis après un an observé dans une autre étude. Depuis qu'il a démontré que les termites mangeaient la plupart des paillis, une étude plus approfondie est nécessaire pour déterminer quels sont les paillis autours des fondations de bâtiments qui peuvent abriter ou supporter des colonies de termites. 
Zusammenfassung. Unterirdische Termiten leben in Kolonien im Boden in allen gemäßigten und tropischen Regionen dieser Welt. Diese Termiten fressen Zellulose und sind damit ein Hauptgrund für Schäden an verarbeitendem Holz. Organische, auf Holz basierende Mulche liefern eine Reihe von Vorteilen für den Landschaftsbau. Dennoch sind kürzlich Fragen darüber aufgetaucht, ob diese organischen Mulche nicht vielleicht eine Brutstätte oder eine Futterquelle für die Termiten sein könnten. In einer Serie von Fütterungsexperimenten haben wir untersucht, ob die Termiten sechs Mulche aus dem Landschaftsbau (Zypresse, Eucalyptus Melaleuca, Kieferninde, Kiefernnadeln und Grasschnitt) und fünf verschiedene Holzsorten (Kiefernsplintholz, Zypressenkernholz und -splintholz, sowie Melaleucasplint- und kernholz) konsumieren, In den Holzexperimenten fraßen die Termiten das Kiefern- und Zypressensplintholz, aber nicht das Zypressenkernholz und nichts von der Melaleuca. Im ersten Experiment fraßen die Termiten von dem Grasschnitt vorzugsweise mehr als von den anderen Mulchen und von dem Kiefernsplintholz. Melaleuca war in allen Versuchen am wenigsten angegangen. Im zweiten Experiment konsumierten die Termiten alle Mulche außer Melaleuca. Die Korrelationen mit den chemischen Eigenschaften war für $\mathrm{N}$ und $\mathrm{P}(\mathrm{r}=$ 0.91 und 0.96) signifikant, was darauf hin deutet, daß mit steigenden $\mathrm{N}$ und $\mathrm{P}$ Konzentrationen die Termiten mehr Mulch fraßen. In beiden Experimenten war der Verzehr der Termiten korreliert mit der einjährigen Versetzung des Mulches in beiden Versuchen. Da die Termiten nun überwiegend Mulche mochten, werden weitere Untersuchungen nötig sein, um $\mathrm{zu}$ bestimmen, welche im Landschaftsbau verwendeten Mulche um Hausfundamente Termiten beherbergen oder ihnen Schutz bieten würden.
Resumen. Las termitas subterráneas viven en colonias dentro del suelo en regiones templadas y tropicales en todo el mundo. Estas termitas que se alimentan de celulosa, son la mayor causa de daño en la madera en uso. Los mulches orgánicos basados en árboles proveen muchos beneficios al paisaje, sin embargo, recientemente han aparecido interrogantes acerca de si ellos podrían albergar o ser una fuente de alimento para colonias de termitas. En una serie de dos experimentos de comida no seleccionada investigamos si las termitas consumirian seis mulches para paisaje (ciprés, eucalipto, melaleuca, corteza de pino, paja de pino y mulch resultante de podas) y cinco maderas (albura de pino, albura y duramen de ciprés y albura y duramen de melaleuca). En los experimentos con madera las termitas consumieron albura de pino y ciprés, pero no consumieron duramen de ciprés o albura y duramen de melaleuca. En el experimento 1 las termitas comieron el mulch resultante de podas más que cualquier otro mulch y que el control con albura de pino. El mulch de melaleuca fue la comida menos deseable en ambos experimentos. En el experimento 2 las termitas consumieron todos los mulches excepto el melaleuca. Correlaciones con características químicas fueron significativas para $\mathrm{N}$ y $\mathrm{P}$ ( $\mathrm{r}=0.91$ y 0.96 ), mostrando que si las concentraciones de $\mathrm{N}$ y $\mathrm{P}$ aumentan, las termitas comen más mulch. En ambos experimentos el consumo de las termitas fue también correlacionado con mulches descompuestos durante un año en otro estudio. Ya que se mostró que las termitas comen más mulches, es necesario realizar otra investigación para determinar si los mulches de paisaje alrededor de cimientos de edificios podrían albergar o sustentar colonias de termitas. 